\title{
Effect of length of utilization on fungi colonizing plant roots, rhizosphere and seeds of fodder galega (Galega orientalis Lam.)
}

\author{
Wpływ długości okresu użytkowania rutwicy wschodniej \\ (Galega orientalis Lam.) na grzyby zasiedlające korzenie, \\ ryzosferę oraz nasiona
}

Małgorzata Jeske ${ }^{1}$, Dariusz Pańka ${ }^{1}$, Stanisław Ignaczak $^{2}$

Summary

The aim of the study was to determine the effect of the length of the fodder galega utilization period on species composition and number of fungi isolated from rhizosphere, rhizoplane and from seeds. Fodder galega plants used for the research were cultivated for the following time length: I - 18-19-years, II - 8-9-years, III - 4-5-years, IV - 3-4-years. Analyses were conducted in 2009-2010. In total 953 colonies of fungi were isolated from roots including 476 colonies in 2009 and 477 in 2010 . Cylindrocarpon destructans was the most frequently isolated species (18.5\%) in the first year of the study, whereas Trichoderma koningii - was the most often isolated fungus in the second year (26.7\%). More than 3.000 isolates representing 43 species were isolated from soil. Penicillium spp., T. viride and $T$. koningii were the most frequently isolated fungi in both years of the study. The highest number of fungi was isolated from roots and from soil in combinations with short period of fodder galega utilization. Ten species of fungi were identified on seeds. Alternaria alternata, Aureobasidium pullulans, Epicoccum purpurascens, Cladosporium herbarum, Stemphylium botryorum, T. koningii and Penicillium spp. were the most often isolated fungi.

Key words: fodder galega; cultivation period; roots healthiness; seeds; pathogens; saprotrophs

\section{Streszczenie}

Celem przeprowadzonych badań było określenie wpływu długości okresu użytkowania plantacji rutwicy wschodniej na skład gatunkowy i liczebność grzybów rozwijających się w ryzosferze i ryzoplanie korzeni oraz na nasionach. Materiał badawczy stanowiła rutwica wschodnia, która w latach badań była w następującym wieku: I - rośliny 18-19-letnie, II - rośliny 8-9-letnie, III - rośliny 4-5-letnie, IV - rośliny 3-4-letnie. Analizy gleby i korzeni przeprowadzono w latach 2009-2010. Z pobranych korzeni wyizolowano ogółem 953 kolonii, w tym w 2009 roku - 476, a w 2010 roku - 477. W pierwszym roku badań dominował gatunek Cylindrocarpon destructans, który stanowił 18,5\% wszystkich izolowanych grzybów, natomiast w roku 2010 Trichoderma koningii - 26,7\%. Z gleby wyizolowano ponad 3000 grzybów należących do 43 gatunków. Najliczniej występowały: Penicillium spp., T. viride i T. koningii. Najwięcej grzybów, zarówno z korzeni, jak i z gleby izolowano w kombinacjach o krótkim okresie użytkowania rutwicy wschodniej. Na nasionach zidentyfikowano 10 gatunków grzybów. Najczęściej izolowano saprotrofy: Alternaria alternata, Aureobasidium pullulans, Epicoccum purpurascens, Cladosporium herbarum, Stemphylium botryosum, T. koningii i Penicillium spp.

Słowa kluczowe: rutwica wschodnia; okres użytkowania; zdrowotność korzeni; nasiona; grzyby patogeniczne; grzyby saprotroficzne

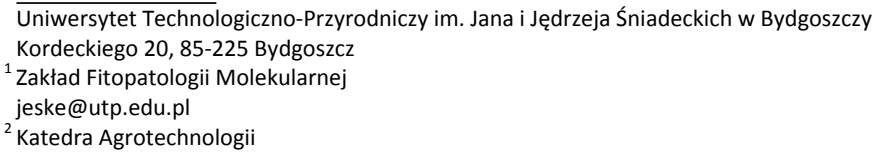




\section{Wstęp / Introduction}

Rutwica wschodnia (Galega orientalis Lam.) (bobowate) jest wieloletnią, drobnonasienną rośliną pastewną, charakteryzującą się dużą odpornością na porażenie przez sprawców chorób (Valkonnen 1993; Kegler i Spaar 1996). Jest introdukowana i uprawiana na zielonkę w wielu krajach europejskich, zwłaszcza o chłodniejszym klimacie. Ze względu na brak wyspecjalizowanych agrofagów charakteryzuje się dużą trwałością na jednym stanowisku, wysoką produkcyjnością zielonej masy, szczególnie na wiosnę oraz wiernością plonowania. Bardzo efektywnie wiąże azot atmosferyczny. Nadaje się do uprawy na terenach zdegradowanych, gdzie jako trwały użytek zielony, tzw. ugór obsiany, chroni glebę przed zachwaszczeniem i innymi formami degradacji, jak niszczenie przez erozję wodną czy też inne niesprzyjające warunki atmosferyczne. Rutwica wschodnia jest rośliną dobrze spełniająca wymogi biologicznej rekultywacji gleby (Ignaczak 2009, 2010). Pomimo dużej odporności na czynniki chorobotwórcze, a tym samym brak widocznych objawów porażenia, rutwica wschodnia może być w kolejnych latach użytkowania infekowana przez patogeniczne grzyby - czynnik potencjalnie ograniczający plonowanie. Dotyczy to głównie korzeni rośliny, które rozwijają się w środowisku o szczególnie wysokiej presji patogenów.

Hipoteza robocza zakłada wzrost zagrożenia dla rutwicy wschodniej ze strony patogenów glebowych wraz z wydłużaniem się okresu użytkowania plantacji. Wieloletnia uprawa zakłóca naturalną równowagę pomiędzy mikroorganizmami w glebie i może sprzyjać nadmiernemu rozwojowi grzybów potencjalnie patogenicznych dla rutwicy wschodniej, a także dla roślin następczych. Ponadto, może również mieć wpływ na wzrost liczebności i skład gatunkowy grzybów zasiedlających nasiona badanego gatunku.

\section{Materiały i metody / Materials and methods}

Badania nad wpływem okresu użytkowania plantacji rutwicy wschodniej na skład gatunkowy i liczebność grzybów rozwijających się $\mathrm{w}$ ryzosferze i ryzoplanie korzeni oraz na nasionach przeprowadzono w doświadczeniach łanowych - polach reprodukcyjnych tej rośliny, zlokalizowanych w Stacji Badawczej Wydziału Rolnictwa i Biotechnologii Uniwersytetu TechnologicznoPrzyrodniczego w Mochełku koło Bydgoszczy. Rośliny do badań pochodziły $\mathrm{z}$ pola, którego gleba należała do kompleksu żytniego dobrego i żytniego słabego. Materiał badawczy stanowiły rośliny rutwicy wschodniej, która w latach badań była w następującym wieku: I - rośliny 18-19-letnie, II - rośliny 8-9-letnie, III - rośliny 4-5-letnie, IV - rośliny 3-4-letnie. Analizy gleby i korzeni przeprowadzono w latach 2009-2010.

Wszystkie pola z rutwicą wschodnią, z których pobrano materiał do badań były obsiewane wiosną, w siewie czystym, w rozstawie rzędów $40 \mathrm{~cm}$. W drugim roku uprawy rośliny rozwijając rozłogi, z reguły zarastały międzyrzędzia. Zasobność gleb w makroskładniki utrzymywano na poziomie średnim do wysokiego. Gleby charakteryzowały się przeważnie lekko kwaśnym odczynem z tendencją do zakwaszania wraz z wiekiem plantacji. Zachwaszczenie skutecznie ograniczano poprzez stosowanie herbicydu zawierającego substancję czynną glifosat, wiosną przed ukazaniem się zaczątków pędów. Od 3. roku uprawy na wszystkich polach rośliny rozwijały się podobnie, toteż stan zaawansowania ich rozwoju w momencie pobierania prób był zbliżony. Starsze rośliny (obiekty I i II) charakteryzowały się większą bujnością (wysokością i zagęszczeniem) na plantacji, a tym samym większą tendencją do wylegania.

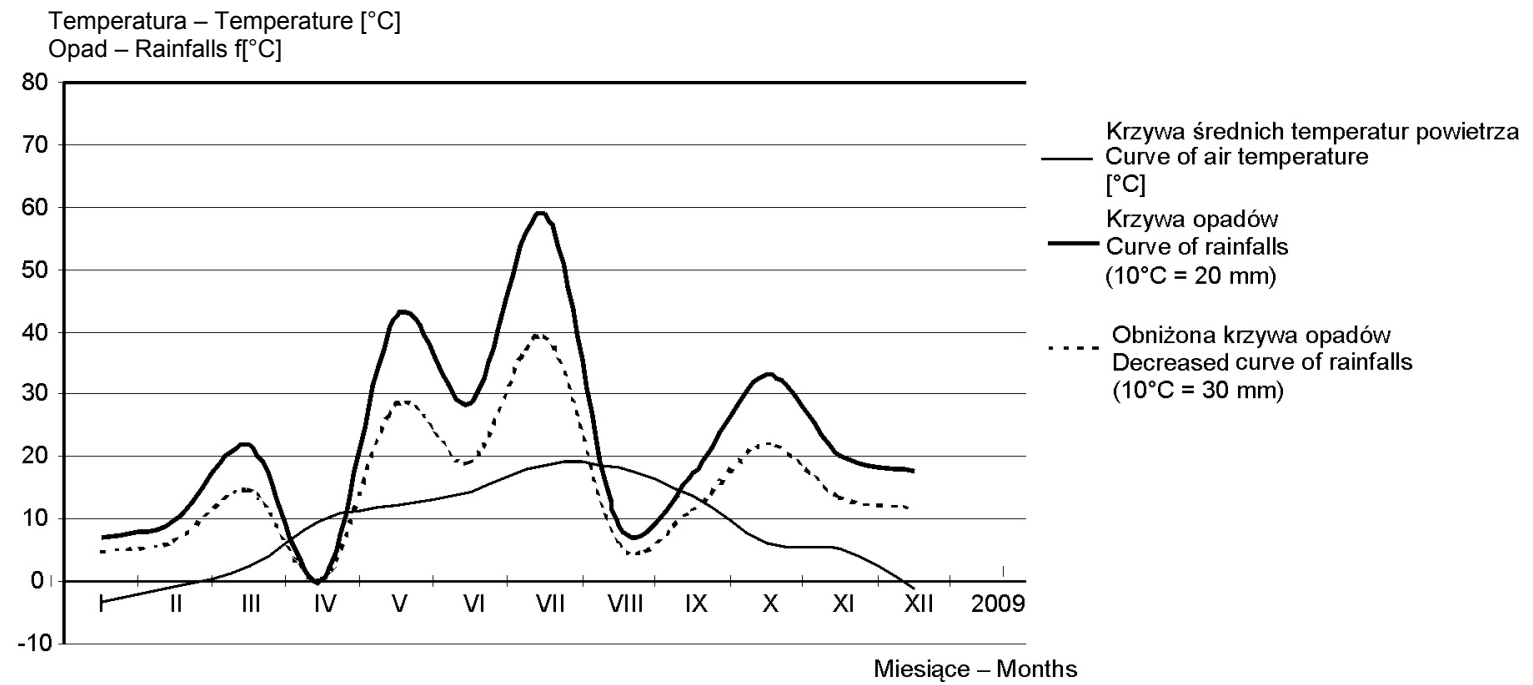

Rys. 1. Warunki pogodowe w okresie prowadzenia badań, Mochełek 2009. Objaśnienie: rzut pionowy na oś czasu obszaru wyznaczonego przez krzywą opadów poniżej krzywej temperatur = okres suchy; rzut pionowy na oś czasu obszaru wyznaczonego przez obniżoną krzywą opadów poniżej krzywej temperatur = okres półsuchy

Fig. 1. Weather conditions during research, Mochełek 2009. Explanation: the vertical projection on the timeline of the area delimited by the precipitation curve below the curve of temperature $=$ the dry period; the vertical projection on the timeline of the area delimited by the reduced precipitation curve below the curve of temperature $=$ period semiarid 
Temperatura - Temperature $\left[{ }^{\circ} \mathrm{C}\right]$

Opad - Rainfalls $\left.f{ }^{\circ} \mathrm{C}\right]$

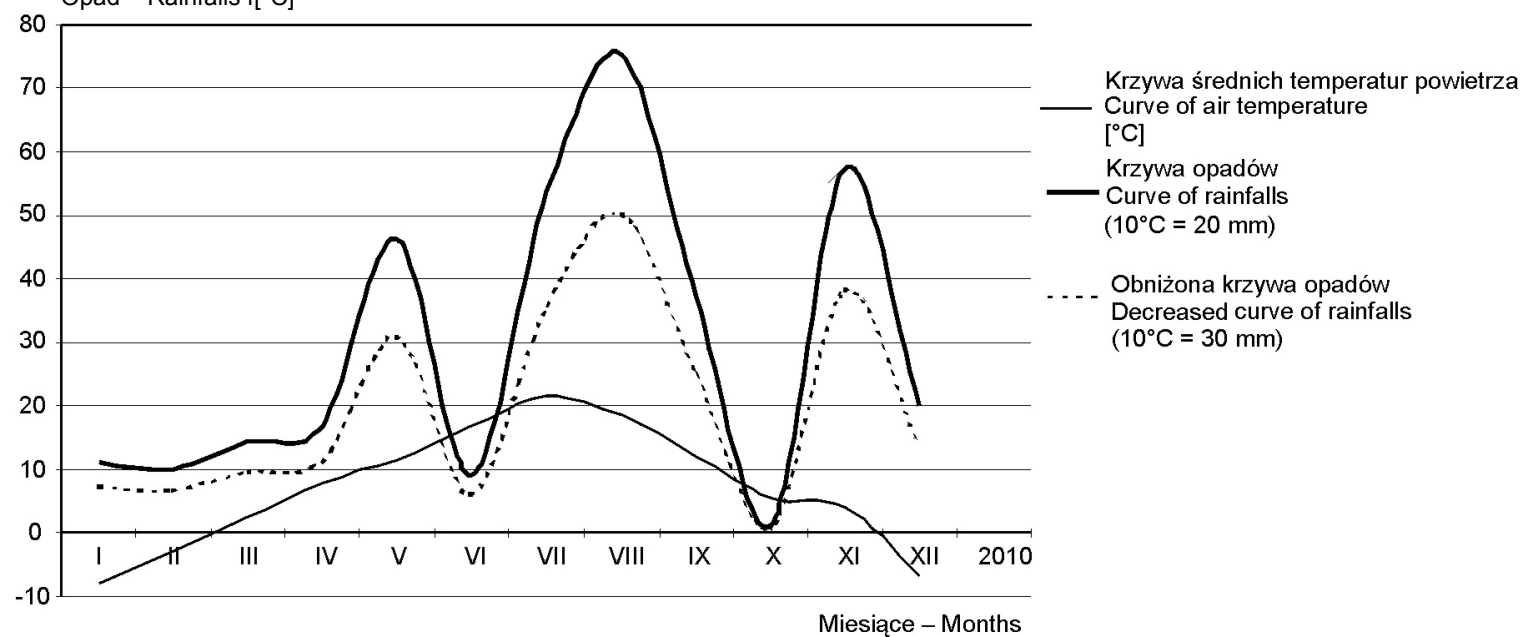

Rys. 2. Warunki pogodowe w okresie prowadzenia badań, Mochełek 2010. Objaśnienie: rzut pionowy na oś czasu obszaru wyznaczonego przez krzywą opadów poniżej krzywej temperatur = okres suchy; rzut pionowy na oś czasu obszaru wyznaczonego przez obniżoną krzywą opadów poniżej krzywej temperatur = okres półsuchy

Fig. 2. Weather conditions during research, Mochełek 2010. Explanation: the vertical projection on the timeline of the area delimited by the precipitation curve below the curve of temperature = the dry period; the vertical projection on the timeline of the area delimited by the reduced precipitation curve below the curve of temperature $=$ period semiarid

W latach badań pogoda charakteryzowała się nierównomiernie rozłożonymi opadami, sumarycznie większymi niż średnia w wieloleciu, szczególnie w roku 2010 (rys. 1, 2). Warunki meteorologiczne sprzyjały rozwojowi wegetatywnemu roślin. W roku 2010 duże opady w lipcu i sierpniu powodowały nadmierny wzrost i znaczne wylegnięcia, szczególnie starszych, bujniejszych roślin, a także duże straty nasion podczas zbioru.

Próby korzeni wraz z glebą pobierano do analiz przed kwitnieniem roślin, w 4 powtórzeniach na każdym $\mathrm{z}$ pól. Zdrowotność analizowano na $100(4 \times 25)$ losowo pobranych próbach korzeni $\mathrm{z}$ każdego pola. Analizę mikologiczną przeprowadzono według ogólnie przyjętych metod izolacji grzybów $\mathrm{z}$ fragmentów roślin. Hodowle szczepów prowadzono na szalkach Periego z zestaloną pożywką PDA (Potato Dextrose Agar). Do pożywki został dodany kwas cytrynowy w celu uniemożliwienia wzrostu bakterii. Szalki były przechowywane w temperaturze pokojowej. Wyrosłe kolonie grzybów były odszczepiane na skosy $\mathrm{z}$ zestaloną pożywką glukozowo-ziemniaczaną. Izolację grzybów $\mathrm{z}$ ryzosfery przeprowadzono metodą piaskową Warcupa zmodyfikowaną przez Mańkę (Mańka i Salmanowicz 1987). W roku 2010 określono zasiedlenie zebranych nasion rutwicy przez grzyby patogeniczne i saprotroficzne. Analizowano po 100 nasion pobranych $\mathrm{z}$ masy plonu pozyskanego z każdego z pól. Wyrosłe kultury grzybów identyfikowano posługując się kluczami mikologicznymi (Gilman 1971; Barron 1972; Domsch i Gams 1972; Barnett i Hunter 1998; Leslie i Summerell 2006).

\section{Wyniki i dyskusja / Results and discussion}

W wyniku przeprowadzonych badań wyizolowano ogółem 953 kolonii grzybów z korzeni rutwicy wschod- niej, w tym w 2009 roku - 476, a w 2010 roku - 477 (tab. 1). W pierwszym roku badań wśród izolatów dominował gatunek Cylindrocarpon destructans, który stanowił 18,5\% wszystkich izolowanych grzybów, natomiast w roku 2010 Trichoderma koningii - 26,7\%. Ponadto, licznie występowały także Rhizoctonia solani, T. viride, Penicillium spp., Mucor mucedo oraz gatunki rodzaju Fusarium, wśród których dominowały: $F$. avenaceum, $F$. equiseti, $F$. oxysporum, $F$. poae i $F$. solani. Nieliczne badania krajowe dotyczące zbiorowiska grzybów korzeni rutwicy wschodniej, również potwierdzają występowanie wyżej wymienionych gatunków rodzaju Fusarium (Cwalina-Ambroziak i Sienkiewicz 2008a).

Analiza mikologiczna gleby pochodzącej $\mathrm{z}$ pola, na którym uprawiano rutwice wschodnią wykazała bardzo duże zróżnicowanie gatunkowe wśród izolowanych grzybów (tab. 2). Ogółem uzyskano ponad 3000 grzybów należących do 43 gatunków. Podobnie Cwalina-Ambroziak i Sienkiewicz (2008b), najbogatsze pod względem ilościowym zbiorowisko grzybów stwierdzili w ryzosferze rutwicy wschodniej. W latach badań najliczniej izolowanymi gatunkami były: Penicillium spp., T. viride i T. koningii. Wśród pozostałych izolatów w pierwszym roku badań dominowały Paecilomyces liliacinus, Phoma glomerata oraz Verticillium tenerum, natomiast w drugim roku Absidia glauca, Mortierella hyalina oraz Fusarium oxysporum. Wielu autorów w swoich pracach do najpospolitszych grzybów środowiska glebowego również zalicza przedstawicieli takich rodzajów, jak m.in. Penicillium, Trichoderma, Verticillium, Fusarium, Mucor (Dorenda 1986; Kołwzan i wsp. 2005).

Udział patogenów izolowanych zarówno z korzeni, jak i z gleby pobieranej z uprawy rutwicy kształtował się na zbliżonym poziomie. Ograniczenie liczebności powyższych grzybów w kolejnych latach badań było prawdopodobnie spowodowane występowaniem znacznej ilości 
Tabela 1. Skład gatunkowy i liczebność grzybów wyizolowanych z korzeni rutwicy wschodniej w zależności od długości okresu użytkowania [łączna liczba wyizolowanych kolonii]

Table 1. Species composition and number of fungi isolated from roots of fodder gallega in relation to length of the period of utilization [total number of isolated colonies]

\begin{tabular}{|c|c|c|c|c|c|c|c|c|c|c|c|c|}
\hline \multirow{3}{*}{ Grzyby - Fungi } & \multicolumn{12}{|c|}{ Lata badań - Years of research } \\
\hline & \multicolumn{4}{|c|}{2009} & \multicolumn{4}{|c|}{2010} & \multicolumn{4}{|c|}{$2009-2010$} \\
\hline & I & II & III & IV & $\mathrm{I}$ & II & III & IV & I & II & III & IV \\
\hline Absidia spinosa Lendner & - & 4 & 3 & 1 & 11 & 8 & 3 & 3 & 11 & 12 & 6 & 4 \\
\hline Alternaria alternate (Fr.) Keissler & 1 & 2 & - & - & - & 2 & - & 5 & 1 & 4 & - & 5 \\
\hline Aspergillus niger van Tieghem & - & - & 2 & 1 & - & - & - & - & - & - & 2 & 1 \\
\hline Aureobasidium pullulans (Bary) Arnaud & - & - & - & 2 & - & - & - & - & - & - & - & 2 \\
\hline Botrytis cinerea Pers. ex Fr. & - & - & - & - & - & - & - & 2 & - & - & - & 2 \\
\hline Cladosporium herbarum Link:Vries & - & 2 & 3 & 2 & - & 1 & 2 & 3 & - & 3 & 5 & 5 \\
\hline Cylindrocarpon destructans (Zins.) Scholten & 24 & 37 & 16 & 10 & 2 & 4 & - & 6 & 26 & 41 & 16 & 16 \\
\hline Epicoccum purpurascens Ehrenb. ex Schlecht & 2 & - & 1 & 3 & - & 2 & - & 3 & 2 & 2 & 1 & 6 \\
\hline Fusarium avenaceum (Fr.) Sacc. & - & 1 & 3 & 5 & - & 3 & 1 & 3 & - & 4 & 4 & 8 \\
\hline F. equiseti (Corda) Sacc. & 2 & 6 & 11 & 7 & - & 2 & 4 & 4 & 2 & 8 & 15 & 11 \\
\hline F. oxysporum Schlecht. & 2 & 4 & 8 & 16 & 1 & 5 & 5 & 11 & 3 & 9 & 13 & 27 \\
\hline F. poae (Peck) Woll. & 1 & 4 & 6 & 9 & - & 2 & - & - & 1 & 6 & 6 & 9 \\
\hline F. solani (Mart.) Sacc. & - & 3 & 8 & 7 & 4 & 3 & 3 & 9 & 4 & 6 & 11 & 16 \\
\hline Mucor mucedo (L.) Fr. & 3 & 9 & 8 & 1 & 8 & 22 & 16 & 20 & 11 & 31 & 24 & 21 \\
\hline Penicillium spp. & 3 & 7 & 9 & 27 & 2 & 25 & 5 & 10 & 5 & 32 & 14 & 37 \\
\hline Phoma glomerata (Corda) Wollenw. and Hochapfel & - & 1 & 5 & 6 & - & - & - & 6 & - & 1 & 5 & 12 \\
\hline Phoma spp. & - & 2 & 3 & 5 & - & - & - & - & - & 2 & 3 & 5 \\
\hline Pythium spp. & - & 4 & 1 & 2 & - & - & - & - & - & 4 & 1 & 2 \\
\hline Rhizoctonia solani Kuhn & 1 & 1 & 7 & 16 & 25 & 3 & 30 & 31 & 26 & 4 & 37 & 47 \\
\hline Stemphylium botryosum Wallroth & - & 1 & - & - & - & - & - & - & - & 1 & - & - \\
\hline Torula spp. & - & - & 1 & 2 & 2 & 2 & - & 2 & 2 & 2 & 1 & 4 \\
\hline Trichoderma koningii Oudem & 15 & 14 & 8 & 4 & 43 & 21 & 50 & 14 & 58 & 35 & 58 & 18 \\
\hline T. polysporum (Link:Pers) Rifai & 1 & 2 & 6 & 5 & - & - & - & - & 1 & 2 & 6 & 5 \\
\hline T. viride Pers. ex Fr. & 29 & 11 & 10 & 8 & 4 & 8 & 8 & - & 33 & 19 & 18 & 8 \\
\hline Zygorhynchus heterogamous Vuillemin & - & - & 6 & 8 & - & - & 1 & 1 & - & - & 7 & 9 \\
\hline Kolonie niezarodnikujące - Non-sporulating colonies & - & 5 & - & - & 1 & - & - & - & 1 & 5 & - & - \\
\hline Suma - Total & 84 & 120 & 125 & 147 & 103 & 113 & 128 & 133 & 187 & 233 & 253 & 280 \\
\hline
\end{tabular}

I - rośliny 18-19-letnie, II - rośliny 8-9-letnie, III - rośliny 4-5-letnie, IV - rośliny 3-4-letnie

I - 18-19-year plants, II - 8-9-year plants, III - 4-5-year plants, IV - 3-4-year plants

grzybów rodzaju Trichoderma o antagonistycznym działaniu. Dorenda (1986) i Kowalik (1994, 1997) również uzasadniały wysoką zdrowotność traw uprawianych w mieszance $\mathrm{z}$ roślinami motylkowatymi, pomimo dużego zagrożenia przez patogeny glebowe, występowaniem grzybów rodzaju Trichoderma.

Biorąc pod uwagę wiek roślin, więcej grzybów izolowano z gleby z uprawy rutwicy 3- oraz 4-letniej. Stanowiły one prawie $60 \%$ wszystkich izolowanych kolonii. Podobnie wśród pozyskanych izolatów z korzeni badanej rośliny większą ich ilość stwierdzano z kombinacji użytkowanych w okresie 3- oraz 4-letnim. Uzyskane wyniki nie potwierdziły zatem hipotezy roboczej. Nie stwierdzono wzrostu zagrożenia ze strony patogenów wraz ze wzrostem długości okresu użytkowania rutwicy wschodniej.

Przeprowadzona analiza mikologiczna nasion wykazała, że były one w małym stopniu zasiedlone przez grzyby (tab. 3). Zidentyfikowano 10 gatunków grzybów. Wśród izolowanych kultur najczęściej występowały saprotrofy: Alternaria alternata, Aureobasidium pullulans, Epicoccum purpurascens, Cladosporium herbarum, Stemphylium botryosum, T. koningii i Penicillium spp. Tylko niewielki procent stanowiły grzyby patogeniczne rodzaju Fusarium: $F$. culmorum i $F$. avenaceum. Stanowi to podstawę do odrzucenia hipotezy roboczej. Wśród wszystkich pozyskanych izolatów, większą ich liczbę, niemal 40\%, stwierdzano na nasionach z pól użytkowanych w okresie 3-4-letnim. Zanotowano bardzo duży udział $A$. alternata w szczególności izolowanych z nasion 18-19 i 3-4-letnich odpowiednio 79,5 oraz 42,5\%. Cwalina-Ambroziak i Majchrzak (2000) w swoich badaniach również zaliczają ten gatunek do powszechnie zasiedlającego nasiona rutwicy wschodniej. Spośród innych grzybów licznie izolowano E. purpurascens, który stanowił 39,2\% kultur wyosobnionych z nasion roślin 3-4-letnich. Cwalina-Ambroziak i Kurowski (2005) uważają, że kształtowanie się zbiorowiska grzybów zasiedlających nasiona zależy od długości okresu przechowywania. Znacznie większą liczbę kolonii gatunku $A$. alternata autorzy izolowali bezpośrednio po zbiorze lub po krótkim przechowywaniu. 
Tabela 2. Skład gatunkowy i liczebność grzybów wyizolowanych z gleby z uprawy rutwicy wschodniej w zależności od długości okresu użytkowania [łączna liczba wyizolowanych kolonii]

Table 2. Species composition and number of fungi isolated from soil of fodder galega in relation to length of the period of utilization [total number of isolated colonies]

\begin{tabular}{|c|c|c|c|c|c|c|c|c|c|c|c|c|}
\hline \multirow{3}{*}{ Grzyby - Fungi } & \multicolumn{12}{|c|}{ Lata badań - Years of research } \\
\hline & \multicolumn{4}{|c|}{2009} & \multicolumn{4}{|c|}{2010} & \multicolumn{4}{|c|}{ 2009-2010 } \\
\hline & I & II & III & IV & I & II & III & IV & I & II & III & IV \\
\hline Absidia spinosa Lendner & - & 9 & - & 1 & - & - & - & - & - & 9 & - & 1 \\
\hline A. glauca Hagem & - & - & 5 & - & 19 & 21 & 8 & 26 & 19 & 21 & 13 & 26 \\
\hline Cladosporium herbarum Link:Vries & - & 2 & 6 & 1 & 4 & - & - & 10 & 4 & 2 & 6 & 11 \\
\hline Cylindrocarpon destructans (Zins.) Scholten & - & - & - & - & 25 & - & - & 5 & 25 & - & - & 5 \\
\hline Fusarium avenaceum (Fr.) Sacc. & - & - & - & - & 4 & 7 & - & 1 & 4 & 7 & - & 1 \\
\hline F. equiseti (Corda) Sacc. & - & - & 3 & 9 & 3 & 21 & 8 & 27 & 3 & 21 & 11 & 36 \\
\hline F. oxysporum Schlecht. & 1 & 5 & 3 & 15 & 18 & 30 & 38 & 34 & 19 & 35 & 41 & 49 \\
\hline Gliocladium catenulatum Gilman et Abbott & - & 8 & 2 & 1 & 3 & 5 & - & - & 3 & 13 & 2 & 1 \\
\hline Mortierella hyalina (Harz) W. Gams & - & 5 & 6 & 5 & 10 & 12 & 14 & - & 10 & 17 & 20 & 5 \\
\hline Mucor mucedo (L.) Fr. & - & 3 & - & - & 7 & 5 & - & - & 7 & 8 & - & - \\
\hline Paecilomyces liliacinus (Thom) Samson & - & 4 & 8 & 22 & - & 5 & - & - & - & 9 & 8 & 22 \\
\hline Penicillium spp. & 135 & 204 & 222 & 302 & 297 & 233 & 318 & 359 & 432 & 437 & 540 & 661 \\
\hline Phoma glomerata (Corda) Wollenw. and Hochapfel & - & 2 & 24 & 7 & - & 7 & - & 12 & - & 9 & 24 & 19 \\
\hline P. eupyrena Sacc. & - & 1 & 3 & 9 & 3 & - & 8 & 14 & 3 & 1 & 11 & 23 \\
\hline Trichoderma koningii Oudem & 44 & 12 & 14 & - & 42 & 22 & 68 & 54 & 86 & 34 & 82 & 54 \\
\hline T. polysporum (Link:Pers) Rifai & 1 & 1 & 2 & - & - & - & 5 & 3 & 1 & 1 & 7 & 3 \\
\hline T. viride Pers. ex Fr. & 91 & 72 & 48 & 7 & 40 & 40 & 27 & 12 & 131 & 112 & 75 & 19 \\
\hline Verticillium tenerum (Nees ex Pers.) Link & - & 1 & 14 & 5 & 3 & 7 & - & - & 3 & 8 & 14 & 5 \\
\hline Suma - Total & 272 & 329 & 360 & 384 & 478 & 415 & 494 & 557 & 750 & 744 & 854 & 941 \\
\hline
\end{tabular}

I - rośliny 18-19-letnie, II - rośliny 8-9-letnie, III - rośliny 4-5-letnie, IV - rośliny 3-4-letnie

I - 18-19-year plants, II - 8-9-year plants, III - 4-5-year plants, IV - 3-4-year plants

Tabela 3. Skład gatunkowy i liczebność grzybów wyizolowanych z nasion rutwicy wschodniej w zależności od długości okresu użytkowania [łączna liczba wyizolowanych kolonii]

Table 3. Species composition and number of fungi isolated from seeds of fodder gallega in relation to length of the period of utilization [total number of isolated colonies]

\begin{tabular}{l|c|c|c|c}
\hline \multicolumn{1}{c|}{ Grzyby - Fungi } & \multicolumn{3}{c}{2010} \\
\cline { 2 - 5 } & I & II & III & IV \\
\hline Alternaria alternate (Fr.) Keissler & 54 & 32 & 4 & 51 \\
Aureobasidium pullulans (Bary) Arnaud & 4 & 6 & - & 17 \\
Cladosporium herbarum Link:Vries & 4 & 5 & 9 & - \\
Epicoccum purpurascens Ehrenb. ex Schlecht & - & 13 & - & 47 \\
Fusarium avenaceum (Fr.) Sacc. & - & - & 1 & - \\
F. culmorum (W.G.Sm.) Sacc. & 2 & - & - & - \\
Penicillium spp. & - & 4 & 4 & 1 \\
Stemphylium botryosum Wallroth & 3 & 1 & - & - \\
Trichoderma koningii Oudem & 1 & - & - & - \\
Kolonie niezarodnikujące - Non-sporulating colonies & - & - & & 1 \\
\hline Suma - Total & 68 & 61 & 55 & 120 \\
\hline
\end{tabular}

I - rośliny 18-19-letnie, II - rośliny 8-9-letnie, III - rośliny 4-5-letnie, IV - rośliny 3-4-letnie

I - 18-19-year plants, II - 8-9-year plants, III - 4-5-year plants, IV - 3-4-year plants

\section{Wnioski / Conclusions}

1. Wśród grzybów izolowanych zarówno z korzeni, jak i z gleby pochodzącej z uprawy rutwicy wschodniej dominowały gatunki saprotroficzne.

2. Spośród grzybów patogenicznych izolowanych z korzeni oraz $\mathrm{z}$ gleby pochodzącej $\mathrm{z}$ uprawy rutwicy wschodniej dominowały gatunki rodzaju Fusarium.
3. Więcej kolonii grzybów izolowano z korzeni oraz z gleby z uprawy rutwicy 3-4- oraz 4-5-letniej.

4. Najliczniej izolowanymi grzybami z materiału siewnego rutwicy wschodniej były gatunki należące do rodzajów: Altenaria, Aureobasidium, Cladosporium i Epicoccum. 


\section{Literatura / References}

Barnett H.L., Hunter B.B. 1998. Illustrated Genera of Imperfect Fungi. APS Press, St. Paul, MN, 241 pp.

Barron G.L. 1972. The Genera of Hyphomycetes from Soil. Krieger Publ. C. New York, 364 pp.

Cwalina-Ambroziak B., Kurowski T.P. 2005. Kształtowanie się zbiorowiska grzybów izolowanych z nasion łubinu żółtego (Lupinus luteus L.) pod wpływem okresu przechowywania. Acta Agrobot. 58 (2): 407-416.

Cwalina-Ambroziak B., Majchrzak B. 2000. Grzyby występujące na nasionach rutwicy wschodniej (Galega orientalis Lam.). Acta Agrobot. 53 (2): 15-23.

Cwalina-Ambroziak B., Sienkiewicz S. 2008a. Effects of mineral fertilization on soil fungal communties of oriental goat's rue Galega orientalis Lam. Pol. J. Natur. Sci. 23 (2): 269-283.

Cwalina-Ambroziak B., Sienkiewicz S. 2008b. Fungi isolated from phyllosphere of fodder galega (Galega orientalis). Acta Mycol. 43 (2): 173-179.

Domsch K.H., Gams W. 1972. Fungi in Agricultural Soils. Longman, London, 290 pp.

Dorenda M. 1986. Badania mikoflory środowiska uprawnego koniczyny czerwonej i kupkówki pospolitej w aspekcie fitopatologicznym. Acta Mycol. 22 (1): 15-34.

Gilman J.C. 1971. A Manual of Soil Fungi. Iowa Univ. Press, Ames, Iowa, 450 pp.

Ignaczak S. 2009. Badania nad możliwością wykorzystania słomy z nasiennych plantacji rutwicy wschodniej (Galega orientalis Lam.) do nawożenia sąsiednich pól. Polskie Towarzystwo Gleboznawcze, Odział w Rzeszowie, Zesz. Nauk. 11: 73-78.

Ignaczak S. 2010. Productivity of seed plantations of fodder galega (Galega orientalis Lam.) cultivated extensively. J. Res. Appl. Agric. Engin. 55 (3): 122-127.

Kegler H., Spaar D. 1996. On the virus susceptibility of Galega orientalis Lam. Arch. Phytopathol. Plant Prot. 30 (3): $187-190$.

Kołwzan B., Adamiak W., Grabas K., Pawełczyk A. 2005. Podstawy mikrobiologii w ochronie środowiska. Oficyna Wydawnicza Politechniki Wrocławskiej, Wrocław, 117 ss.

Kowalik M. 1994. Fungi isolated from the initial industrial soil plantem with a mixure of alfalfa and grasses. Acta Mycol. 29 (1): $69-80$.

Kowalik M. 1997. Grzyby z rodzaju Trichoderma i Gliocladium jako czynnik ograniczający występowanie grzybów patogenicznych $\mathrm{w}$ uprawie mieszanki lucerny $\mathrm{z}$ trawami. [Trichoderma spp. and Gliocladium spp. as factors controlling the occurrence of pathogenic fungi in stands of a mixture of alfalfa and grasses]. Prog. Plant Prot./Post. Ochr. Roślin 37 (2): 390-393.

Leslie J.F., Summerell B.A. 2006. The Fusarium Laboratory Manual. Blackwell Publishing, 388 pp.

Mańka K., Salmanowicz B. 1987. Udoskonalenie niektórych technik zmodyfikowanej metody płytek glebowych do izolowania grzybów z gleby z punktu widzenia potrzeb mikologii fitopatologicznej. Rocz. Nauk Rol., Seria E - Ochrona Roślin, 17 (1): 35-46.

Valkonnen J.P.T. 1993. Resistance to six viruses in the legume goat's rue (Galega orientalis Lam.). Ann. Appl. Biol. 123 (2): $309-314$. 